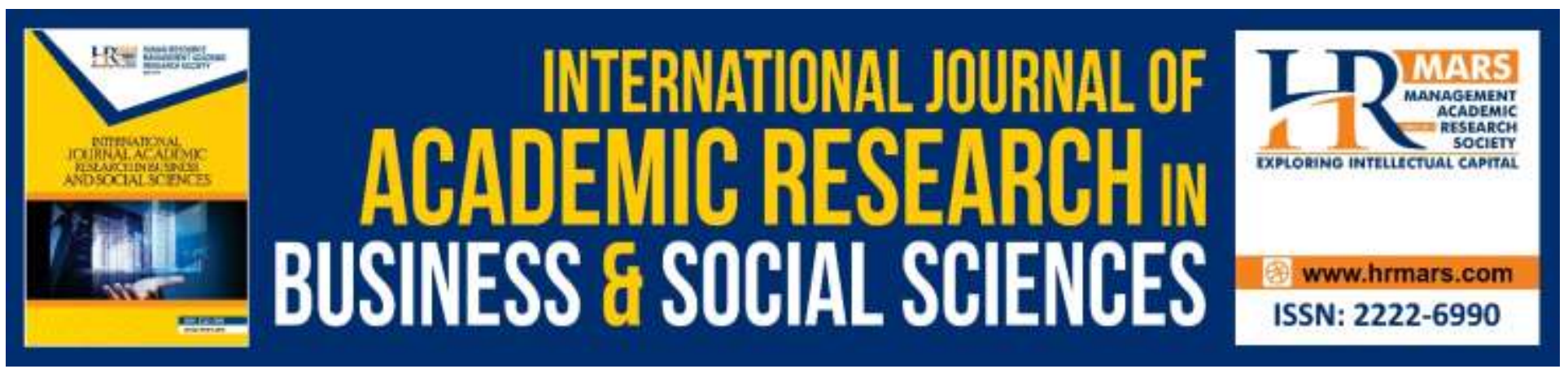

\title{
Students' Perception on YouTube Usage in Rural ESL Classroom
}

Easterly Anak Michael, Parilah Mohd. Shah

To Link this Article: http://dx.doi.org/10.6007/IJARBSS/v10-i3/7059

DOI:10.6007/IJARBSS/v10-i3/7059

Received: 06 February 2020, Revised: 21 February 2020, Accepted: 17 March 2020

Published Online: 29 March 2020

In-Text Citation: (Michael \& Shah, 2020)

To Cite this Article: Michael, E. anak, \& Shah, P. M. (2020). Students' Perception on YouTube Usage in Rural ESL Classroom. International Journal of Academic Research in Business and Social Sciences, 10(3), 410-431.

Copyright: (C) 2020 The Author(s)

Published by Human Resource Management Academic Research Society (www.hrmars.com)

This article is published under the Creative Commons Attribution (CC BY 4.0) license. Anyone may reproduce, distribute, translate and create derivative works of this article (for both commercial and non-commercial purposes), subject to full attribution to the original publication and authors. The full terms of this license may be seen

at: http://creativecommons.org/licences/by/4.0/legalcode

Vol. 10, No. 3, 2020, Pg. 410 - 431

http://hrmars.com/index.php/pages/detail/IJARBSS

JOURNAL HOMEPAGE

Full Terms \& Conditions of access and use can be found at http://hrmars.com/index.php/pages/detail/publication-ethics 


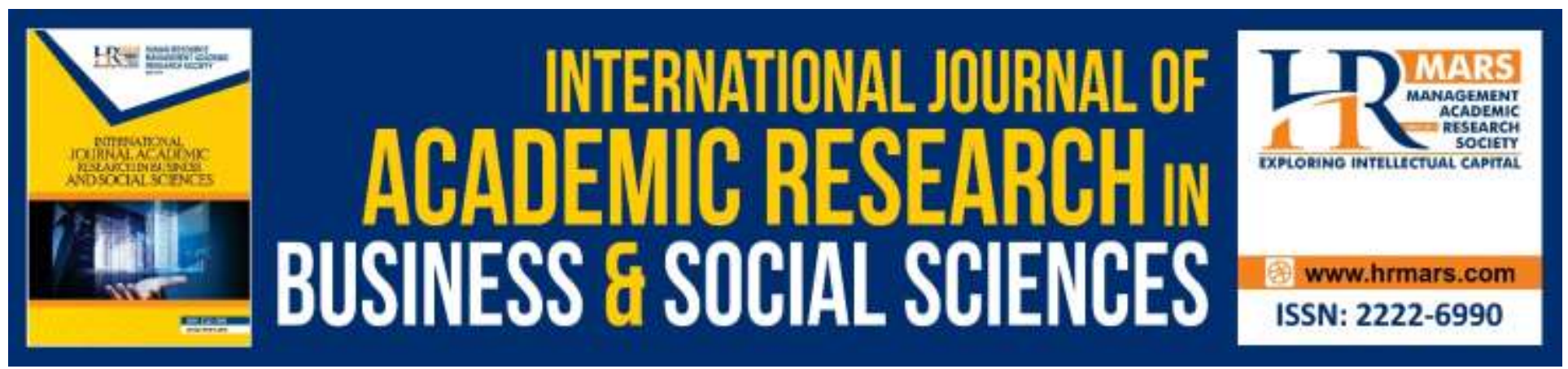

\title{
Students' Perception on YouTube Usage in Rural ESL Classroom
}

\author{
Easterly Anak Michael, Parilah Mohd. Shah \\ SK Rancangan Sepupok, Faculty of Education, Universiti Kebangsaan Malaysia (UKM), 43600 \\ Bangi, Selangor, Malaysia.
}

\begin{abstract}
Technology has been an important part of our daily lives. From older generation to the younger generation, technology is used immensely. One of the great technology that has been invented is the internet that has provided us with various experiences. Through internet, social networking has been developed. One of the social networking websites is the YouTube. YouTube is a social network website which function as a video sharing platform. Users can share their unique videos to their viewers or subscribers. It has brought great changes to the education. It provided teachers with various golden chances to upgrade the quality of the teaching and learning process in the classroom. The usage of YouTube videos is important to accommodate to the $21^{\text {st }}$ century classroom. The usage of YouTube has become a trend among the teachers, including the teachers in the rural area. There are various studies that has been conducted by researchers specifically focussing on the students' perceptions of using YouTube to learn the English language. It is suggested that learners in today's generation have different styles due to their awareness of the existence of the technology. The way students acquire knowledge and acquire new knowledge from watching the YouTube videos in learning English in the classroom. Other studies that were conducted also explored students' perceptions of YouTube as an effective instrument to acquire English among ESL learners.
\end{abstract}

Keywords: YouTube, Perceptions, Interest, Learning Style, ESL Learners.

\section{Introduction}

One of the greatest invention is digital technologies. The existence of digital technologies such as the internet has caused in the born of a new generation of individually literate called the Net Generation (Prensky, 2001). From Net Generation, moving to the Millennials and finally, the latest generation, that is called as the Generation Alpha. Generation Z, that were born at and after the turn of the era of the millennium (Nagy \& Kolcsey, 2017). Generation Z is a generation that will never get a chance to know and experience the life without the Internet. The internet has become one of the important elements in their life. The internet has become an essential element in their life. Hence, their learning styles could be different in their own ways from the previous generations. Thus, 
INTERNATIONAL JOURNAL OF ACADEMIC RESEARCH IN BUSINESS AND SOCIAL SCIENCES Vol. 10, No. 3, March, 2020, E-ISSN: 2222-6990 @ 2020 HRMARS

teachers need to always equip themselves with various interactive methods and ways to increase the motivation and perception of the pupils in the process of acquiring the English language. This is to assist the teachers grasp the attention of the learners effectively.

One of the ways is the adaption of the usage of the YouTube videos in the lesson of the English language. This approach has shifted the pedagogy in the rural school to a new light. A fresh and interactive pedagogy, could have effect and impact on the level of the students' participation and motivation in the rural school. As stated above, the internet has become an essential element in the new generation life. The use of the YouTube videos would complement the usage of the internet in the rural English language classroom. The use of YouTube and other information technology in education has been anticipated as one of the valuable resources to involve new generation students (Duffy, 2008). YouTube has become one of the main resources and tool for the interactive and motivating approach among the teaches in the rural schools to teach English language to the rural students. The invention of the internet and the worldwide web has made the use of YouTube in a rural classroom a possible mission. It is not an impossible mission of using the YouTube videos in the rural English language classroom.

As stated above, the usage of YouTube is important to meet the 21st century classroom to upgrade the quality of the education process of the learners in the English language in the classroom. Video can be an influential teaching and learning medium to seize attention of the learners and can also be a strong stimulus for learning when it is used in a correct way (Whatley \& Ahmad, 2007). The way students acquire knowledge and obtain information from watching YouTube videos in learning English in the classroom is very important since it will help the teachers to identify the students' preference, interest and types of resources that they use to enhance learning process of the English language. Therefore, the use of variety of instructional strategies and activities in the classroom or through online education can help enrich the learning environment of the students (Fill \& Ottewill, 2006).

Due to the idea of using the YouTube videos in the rural classroom is still relatively new, the way of effectively using and handling the approach in the English language learning in the rural classroom is still not definite. Despite the importance of using YouTube to increase the students' participation and motivation in the classroom, almost to none research were conducted to investigate the perceptions of Malaysia rural students in using YouTube in rural ESL classroom. Therefore, this study is done to increase the number of study done on this purpose. The purpose of the study is to explore the use of YouTube in the ESL classroom by surveying students' perceptions and the students' insights on the effectiveness of using YouTube to learn English specifically a rural primary school in Niah, Sarawak. This study also aims to investigate their interest in using YouTube in ESL classroom specifically a rural primary school in Niah, Sarawak. Lastly, it intended to explore the students' suggestions and comments about the usage of YouTube in learning English at a particular rural primary school in Niah, Sarawak. In short, the research questions were as follows:

1. What are the interests of the students in the usage of YouTube in learning English at a particular rural primary school in Niah, Sarawak?

2. What are the students' perceptions of using YouTube in the ESL classroom at a particular rural primary school in Niah, Sarawak?

3. What are the students' insights on the effectiveness of the usage of YouTube in learning English at a particular rural primary school in Niah, Sarawak? 
INTERNATIONAL JOURNAL OF ACADEMIC RESEARCH IN BUSINESS AND SOCIAL SCIENCES

Vol. 10, No. 3, March, 2020, E-ISSN: 2222-6990 @ 2020 HRMARS

4. What are the students' suggestions and comments about the usage of YouTube in learning English at a particular rural primary school in Niah, Sarawak?

\section{Literature Review}

One of the famous videos sharing platform is YouTube. The official website address for YouTube is www.youtube.com. YouTube is a world renowned video sharing platform where users can choose whether to share or view video clips (Duffy, 2008). Based on the statistical report on its official website, there are a great deal of people visiting the website. In the website, there are various categories of videos in many languages available for viewing. One of the main languages of the videos shared in the YouTube is the English language. Thus, with various choices of videos, teachers can choose various videos to be used in the rural classroom to expose students to the language. Various meaningful activities could be conducted in the rural classroom to improve the four main skills of the students which are the listening, speaking, reading and writing skill. Examples of activities can be from conversational activities, 'film trailer', 'voiceover' to 're-enactments of famous movies' which can be used for listening and speaking activities (Watkins \& Wilkins, 2011). Video could be used in various ways such as instructional sequences, simulations, talking head, video diaries, video help, video labs, and so on (Willmot, Bramhall \& Radley, 2012). The students would have the opportunities to use the videos as the tool and platform for their improvement and learning of the English language. Kreisen (2009) viewed that it has helped pupils to learn more about other nations and cultures due to the fact that the videos can be uploaded by anyone from various groups of people. It also encouraged learners to share their videos that could provide constructive output for learning (Snelson, 2009). Stempleski (2001) agreed that YouTube videos can attract the students' interest to pay attention better due to the audio and visual aids provided.

\section{YOUTUBE for $21^{\text {st }}$ Century Learning in Rural ESL Classrooms}

Due to the idea of using the YouTube videos in the rural primary school is still relatively new, the way of effectively using and handling the approach in the English language learning in the rural classroom is still not definite. Nevertheless, the usage of YouTube and other innovative technology resources in the teaching and learning process of the English language has widespread among the English teachers and students. Several researchers from various background or demographic suggested that using ICT in the classroom is becoming more dominant as one of the resources in the classroom (Brunner, 2013). In Malaysia, the Ministry of Education has implement the $21^{\text {st }}$ century classroom. One of the aspects of the $21^{\text {st }}$ century classroom is the integration of ICT in the classroom. One of the easy access of the ICT is the usage of the internet. Through the internet, the teachers can use the YouTube. The current trend of the teachers is to use YouTube as the resources. It allows learners to be involved and take part actively and interactively in the English language learning classroom. The younger generation nowadays use technologies in particular the internet more compared to the other technologies as a medium of socialization (Mishna et al, 2009). Therefore, educators need to equip themselves with the integration of the technology and integrate YouTube into the learning process to suit with the pupils' preferences and curiosity thus will make learning process more exciting (Gunadevi, Fathimah \& Raja, 2013). 
INTERNATIONAL JOURNAL OF ACADEMIC RESEARCH IN BUSINESS AND SOCIAL SCIENCES

Vol. 10, No. 3, March, 2020, E-ISSN: 2222-6990 @ 2020 HRMARS

\section{YOUTUBE, Students' Motivation and Learning Preferences}

YouTube, undeniably give an impact to the students' motivation in learning English language, specifically positive impacts. As stated by Berk (2009), are able to give a strong effect on their minds and senses. Videos can be useful to the teachers. Videos can be used by the teacher to attract the pupils' attention and improve their concentration. Furthermore, videos can make the students to be interested in the learning. Thus, this will improve the quality of the learning. It can be used to enhance the understanding and imagination of the students. In the end, this will make the learning fun and meaningful. Berk (2009) stated that YouTube videos not limited to be able to entice the learners' attention only, but can accommodate varieties of learning styles namely emotional intelligences, musical, verbal, and visual. The watching of the videos also permitted the brain to react actively to both side of the brain which helps to increase and boost the students' understanding (Berk, 2009). Students' motivation to learn is much relies on their learning styles.

Many learning styles has been proposed and introduce by many scholars. Three learning modalities has been proposed by Walter Burke Barbe. The learning modalities is referred to as VAK which stands for visual (V), auditory(A) and kinesthetic(K) learning. In this model, it is a mixture of preferences, strengths and personality of each individual. Later on, the VAK model was refine by Flemming and Mills (1992). The model is known as Neil Fleming's VARK model. The four main sensory models in Fleming's model are visual learning, auditory learning, read/write learning and kinesthetic learning.

Furthermore, Fleming and Mills (1992) claimed that visual learners prefer to see visual aids that represented concepts using methods other than words, such as charts, diagrams, graphs, symbols and others. Meanwhile, auditory learners learn better through the usage of music or sounds. Whereas tactile learners prefer hands-on activity. Hence, the selection of YouTube among students is highly influenced by their learning styles, preferences and interest.

Other than that, Duffy (2008) suggested several specific examples on how YouTube could be integrated and embedded into teaching and learning in ESL classroom. One of the activities that could be implemented is asking the students to create a video as a part of an evaluation and upload it on the YouTube. The use of the comment section, it could be used as a platform for discussion and improvement for future project.

Another research was conducted by Roodt and De Villiers (2011). The study focused on the usage of YouTube as one of the instruments to support cooperative learning. The study was conducted at the University of Pretoria on one of the course offered. The course comprised of a group project where students were assigned to use YouTube as a tool to create a video on how businesses can use Web 2.0 technologies amongst other tasks. It was reported that based on a sample of 185 students, it was found that YouTube was perceived as an advanced learning technology by the majority of the samples instead of the traditional method (Roodt \& De Villiers, 2011).

Tan and Pearce (2012) agreed that the usage of the YouTube videos has an impact where it has assisted students to describe key concepts in a sociology course. They used videos as an introductory sociology course at Durham University. Tan and Pearce (2012) added that the usage of YouTube videos assisted the students' learning and understanding process. In conclusion, as educators think that using YouTube as one of the main resources, it is also crucial for educators to 
reflect on the suitable materials to be used in the classroom because each student has different preferences and learning styles.

There is one study on students' perceptions of YouTube usage in the English oral communication classroom conducted by Gunadevi, Fathimah and Raja (2013). Moreover, to date researches are being carried out by educators in Malaysia pertaining to the students' interest and perception of using YouTube videos in ESL classroom in Malaysia. The research can provide information on the levels of exposure of students' perceptions and attitudes towards the usage of the YouTube videos in the classroom as a learning resources for English language classroom. In addition, this study would help teachers to know their students' preferences whether they prefer to use or prefer not to use YouTube in the lesson. This is to engage learners in listening, speaking, reading and writing skills activities effectively. Besides that, this study can also help teachers to adopt the usage of YouTube effectively in the English language learning classroom to enhance students' proficiency level and students' participation in the lessons. The researcher noticed that there is a lack of studies, which studied the effect of YouTube in English language and little empirical research existed that demonstrated how web-based applications can be integrated into language learning in Malaysia.

\section{Instrument and Sampling}

This study is descriptive and use a quantitative method. It consists of a questionnaire-based survey. The questionnaire-based survey was administered to rural students. The questionnaire was adopted and adapted from Zaidi et al., 2018. The questionnaires were divided into three sections. The first section of the questionnaire included the demographic information of the respondent which would include the respondents' age, gender and level of language proficiency. The second part consisted of ten questions using Likert-scale which related to the students' interest on their usage of YouTube. The final ten questions focus on their perceptions of using YouTube in ESL class. Questionnaires were constructed in order to answer the two research questions. The research questions are what are the interests of the students in the usage of YouTube in learning English at a particular rural primary school in Niah, Sarawak and what are the students' perceptions of using YouTube in the ESL classroom at a particular rural primary school in Niah, Sarawak. The sample of the study $(n=120)$ is Year 6 pupils of rural schools in Niah, Sarawak. The questionnaires were made use of the Likert scale ranging from $1=$ Strongly Disagree, $2=$ Disagree, $3=$ Neutral, $4=$ Agree and $5=$ Strongly Agree.

\section{Procedure and Data Collection}

Students were selected randomly as participants in the survey. The questionnaires were then distributed and the students were given a brief briefing on how to answer the questionnaire. The students were also being assured that their data would be kept confidential at all time. The researcher made the students understood that their answers should reflect on their honest beliefs, thoughts and feelings. Students were also informed that the involvement in the survey was own freewill and anonymous. Since participation was voluntary, the students were given the option to participate or not to participate in the survey that were given to them. 
INTERNATIONAL JOURNAL OF ACADEMIC RESEARCH IN BUSINESS AND SOCIAL SCIENCES Vol. 10, No. 3, March, 2020, E-ISSN: 2222-6990 ¿ 2020 HRMARS

\section{Findings and Data Analysis}

From the findings, the data was analyzed, the responses from the question were tabulated and discussed in later chapters. The results shown that out of 120 samples, a total of 120 completed the survey (100\% response rate), (refer to Table 1$)$. The students were twelve years of age, (refer to Table 1).

Age

\begin{tabular}{|c|c|c|c|c|c|}
\hline & & $\begin{array}{c}\text { Freque } \\
\text { ncy }\end{array}$ & $\begin{array}{c}\text { Perce } \\
\text { nt }\end{array}$ & $\begin{array}{c}\text { Valid } \\
\text { Percent }\end{array}$ & $\begin{array}{c}\text { Cumulative } \\
\text { Percent }\end{array}$ \\
\hline $\begin{array}{c}\text { Vali } \\
\text { d }\end{array}$ & 12 & 120 & 100.0 & 100.0 & 100.0 \\
\hline
\end{tabular}

Table 1

$45.8 \%(n=55)$ of the respondents were male and 54.2\% $(n=65)$ female, (refer to Table 2 and chart 1). Females were the majority of the samples.

Gender

\begin{tabular}{|cc|c|c|c|c|}
\hline & $\begin{array}{c}\text { Frequen } \\
\text { cy }\end{array}$ & $\begin{array}{c}\text { Perce } \\
\text { nt }\end{array}$ & $\begin{array}{c}\text { Valid } \\
\text { Percent }\end{array}$ & $\begin{array}{c}\text { Cumulative } \\
\text { Percent }\end{array}$ \\
\hline & $\begin{array}{c}\text { Fema } \\
\text { le }\end{array}$ & 65 & 54.2 & 54.2 & 54.2 \\
d & Male & 55 & 45.8 & 45.8 & 100.0 \\
& Total & 120 & 100.0 & 100.0 & \\
\hline
\end{tabular}

Table 2

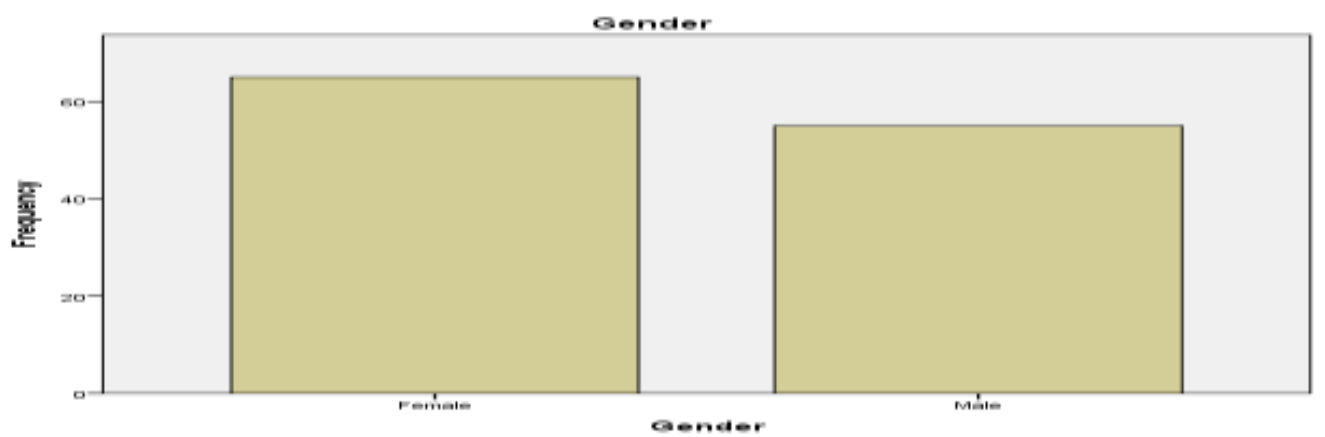

Chart 1: Gender of The Samples.

The data shown that most of the Year Six students are possessing an intermediate level of English proficiency level with 56.7 ( $n=68)$, (refer to Table 3) whereas the advanced students comprise of 
INTERNATIONAL JOURNAL OF ACADEMIC RESEARCH IN BUSINESS AND SOCIAL SCIENCES Vol. 10, No. 3, March, 2020, E-ISSN: 2222-6990 @ 2020 HRMARS

$29.2 \%(n=35)$ and the students with beginners proficiency levels compromise of $14.2 \%(n=17)$. Thus, it can be concluded that most of the respondents possessed intermediate English proficiency levels.

Proficiency

\begin{tabular}{|c|c|c|c|c|c|}
\hline \multicolumn{2}{|c|}{} & $\begin{array}{c}\text { Frequenc } \\
\text { y }\end{array}$ & Percent & $\begin{array}{c}\text { Valid } \\
\text { Percent }\end{array}$ & $\begin{array}{c}\text { Cumulative } \\
\text { Percent }\end{array}$ \\
\hline \multirow{4}{*}{$\begin{array}{c}\text { Vali } \\
\text { d }\end{array}$} & \begin{tabular}{c} 
Beginners \\
\cline { 2 - 6 }
\end{tabular} & 17 & 14.2 & 14.2 & 14.2 \\
\cline { 2 - 6 } & Advermediat & 68 & 56.7 & 56.7 & 70.8 \\
\cline { 2 - 6 } & Advanced & 35 & 29.2 & 29.2 & 100.0 \\
\hline
\end{tabular}

Table 3

The proficiency levels of the samples were also deciphered into Chart 2 as shown below.

Proficiency

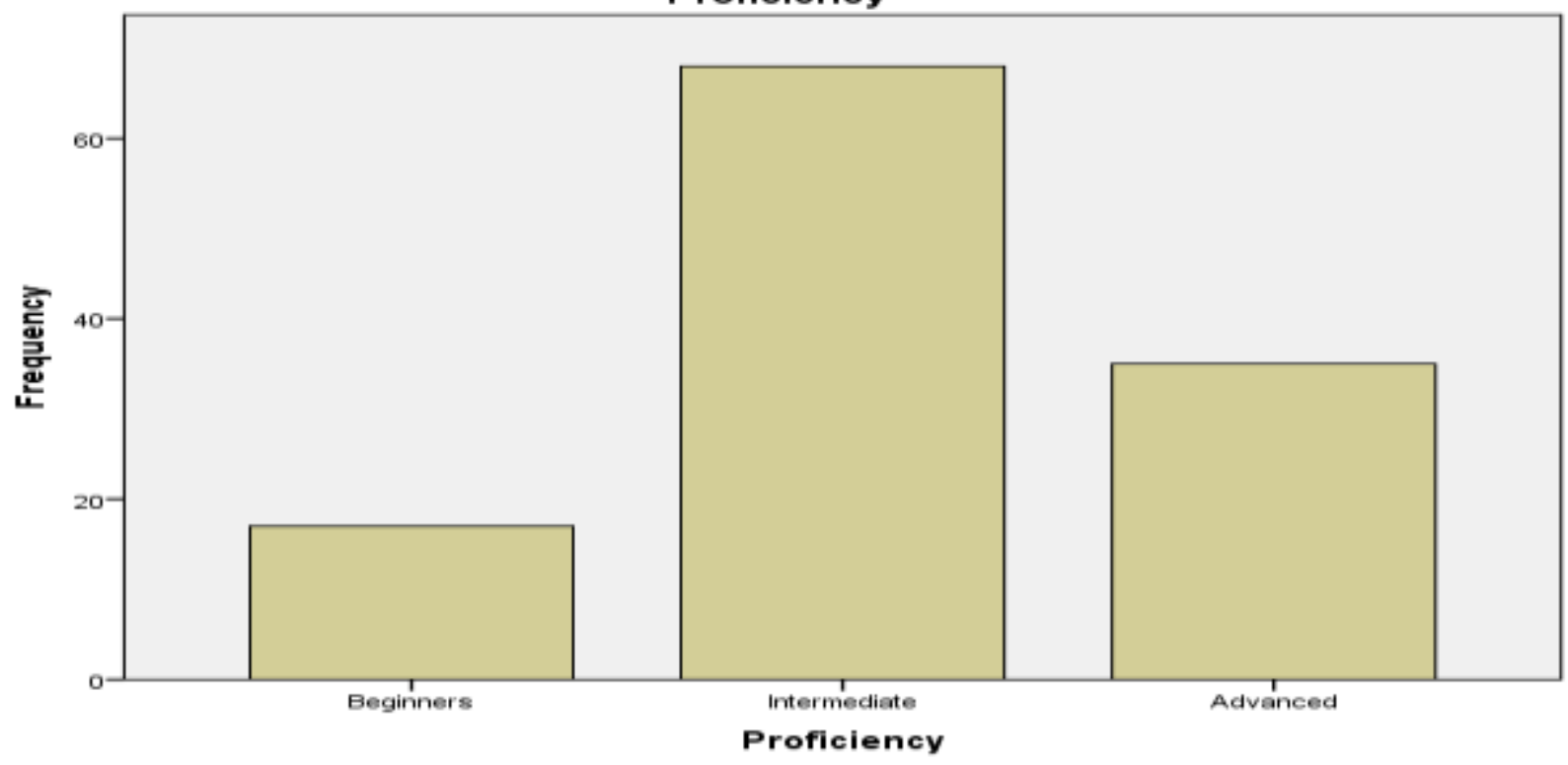

Chart 2: Year Six English Proficiency Level

There were a few statements that had been administered regarding the use of the YouTube videos to investigate their interest and perception. The result of the statements is stated in the tables below. 
INTERNATIONAL JOURNAL OF ACADEMIC RESEARCH IN BUSINESS AND SOCIAL SCIENCES

Vol. 10, No. 3, March, 2020, E-ISSN: 2222-6990 C 2020 HRMARS

YouTube videos makes learning English interesting.

\begin{tabular}{|c|c|c|c|c|c|}
\hline & & $\begin{array}{c}\text { Freque } \\
\text { ncy }\end{array}$ & $\begin{array}{c}\text { Perce } \\
\text { nt }\end{array}$ & $\begin{array}{c}\text { Valid } \\
\text { Percent }\end{array}$ & $\begin{array}{c}\text { Cumulative } \\
\text { Percent }\end{array}$ \\
\hline $\begin{array}{l}\text { sVa } \\
\text { lid }\end{array}$ & $\begin{array}{l}\text { Neutral } \\
\text { Agree } \\
\text { Strongly } \\
\text { Agree } \\
\text { Total }\end{array}$ & $\begin{array}{c}52 \\
120\end{array}$ & $\begin{array}{l}10.8 \\
45.8\end{array}$ & $\begin{array}{l}10.8 \\
45.8\end{array}$ & $\begin{array}{l}10.8 \\
56.7\end{array}$ \\
\hline
\end{tabular}

Table 4

From the table 4, it can be seen that $45.8 \%(n=55)$ of the students agree that YouTube video makes learning English interesting. On the other hand, $43.3 \%(n=52)$ of the students strongly agree YouTube video makes learning English interesting. However, there were 10.8\% $(n=13)$ of the students choose neutral on the statement. Based on the result, majority of the students agreed that the YouTube videos has an impact that makes their learning English more interesting.

YouTube videos makes it easier to learn English in the classroom.

\begin{tabular}{|c|c|c|c|c|c|}
\hline & & $\begin{array}{c}\text { Freque } \\
\text { ncy }\end{array}$ & $\begin{array}{c}\text { Perce } \\
\text { nt }\end{array}$ & $\begin{array}{c}\text { Valid } \\
\text { Percent }\end{array}$ & $\begin{array}{c}\text { Cumulative } \\
\text { Percent }\end{array}$ \\
\hline \multirow{4}{*}{$\begin{array}{c}\text { Vali } \\
\text { d }\end{array}$} & Neutral & 15 & 12.5 & 12.5 & 12.5 \\
\hline & Agree & 62 & 51.7 & 51.7 & 64.2 \\
\hline & $\begin{array}{c}\text { Strongly } \\
\text { Agree }\end{array}$ & 43 & 35.8 & 35.8 & 100.0 \\
\hline & Total & 120 & 100.0 & 100.0 & \\
\hline
\end{tabular}

Table 5

From the table 5, it can be seen that $51.7 \%(n=62)$ of the students agree that YouTube video makes it easier to learn English in the classroom. On the other hand, 35.8\% $(n=43)$ of the students strongly agree YouTube video makes it easier to learn English in the classroom. Although majority of the students agree that YouTube video makes it easier to learn English in the classroom, there were 
INTERNATIONAL JOURNAL OF ACADEMIC RESEARCH IN BUSINESS AND SOCIAL SCIENCES Vol. 10, No. 3, March, 2020, E-ISSN: 2222-6990 C 2020 HRMARS

$12.5 \%(n=15)$ of the students choose neutral on the statement. Based on the result, majority of the students did agree that the YouTube video makes it easier to learn English in the classroom.

YouTube videos enables me to understand English better.

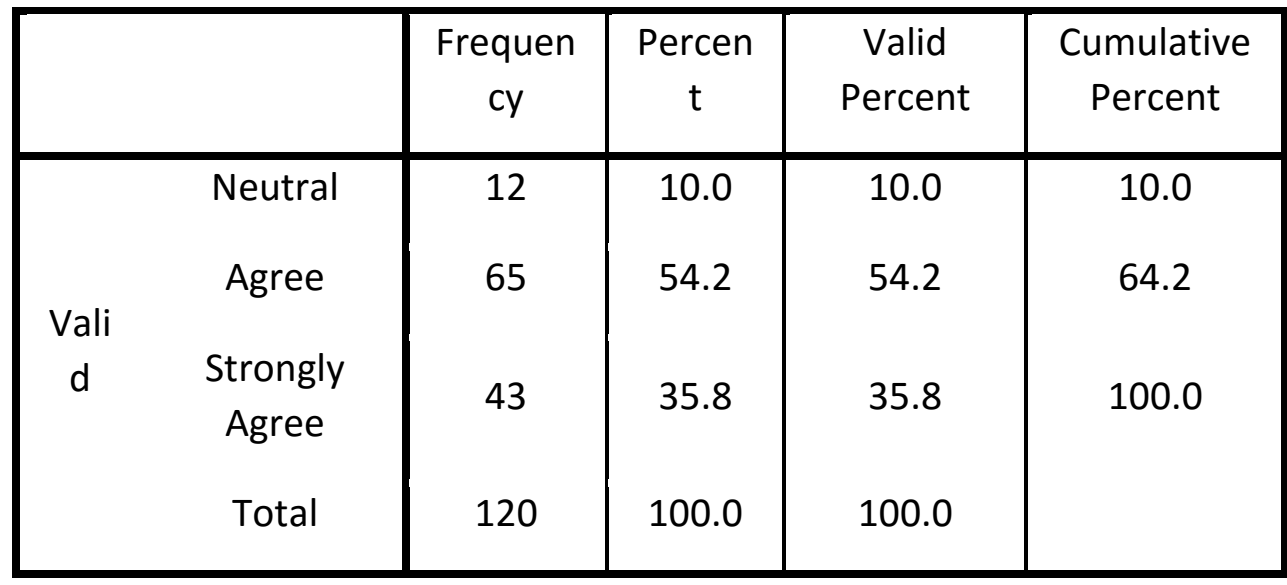

Table 6

From the table 6, it can be seen that $54.2 \%(n=65)$ of the students agree that YouTube videos enables them to understand English better. Whereas, $35.8 \%(n=43)$ of the students strongly agree YouTube videos enables them to understand English better. Despite majority of the students agree that YouTube videos enables them to understand English better, there were $10 \%(n=12)$ of the students choose neutral on the statement. Based on the result, majority of the students did agree that the YouTube videos enables them to understand English better.

The following statements were administered to investigate the students' interest in using YouTube videos.

YouTube videos motivate me to study English when I am outside of the class.

\begin{tabular}{|c|c|c|c|c|c|}
\hline & & $\begin{array}{c}\text { Freque } \\
\text { ncy }\end{array}$ & $\begin{array}{c}\text { Perce } \\
\text { nt }\end{array}$ & $\begin{array}{c}\text { Valid } \\
\text { Percent }\end{array}$ & $\begin{array}{c}\text { Cumulative } \\
\text { Percent }\end{array}$ \\
\hline $\begin{array}{c}\text { Vali } \\
\text { d }\end{array}$ & $\begin{array}{l}\text { Neutral } \\
\text { Agree } \\
\text { Strongly } \\
\text { Agree } \\
\text { Total }\end{array}$ & $\begin{array}{r}44 \\
120\end{array}$ & $\begin{array}{l}10.8 \\
52.5\end{array}$ & $\begin{array}{l}10.8 \\
52.5\end{array}$ & $\begin{array}{l}10.8 \\
63.3\end{array}$ \\
\hline
\end{tabular}

Table 7 
INTERNATIONAL JOURNAL OF ACADEMIC RESEARCH IN BUSINESS AND SOCIAL SCIENCES Vol. 10, No. 3, March, 2020, E-ISSN: 2222-6990 @ 2020 HRMARS

From the table 7, it can be seen that $52.5 \%(n=63)$ of the students agree that YouTube videos motivate them to study English when they are outside of the class. Whereas, $36.7 \%(n=44)$ of the students strongly agree YouTube videos motivate them to study English when they are outside of the class. Despite majority of the students agree that YouTube motivate them to study English when they are outside of the class, there were $10.8 \%(n=13)$ of the students choose neutral on the statement. Based on the result, majority of the students agreed that the YouTube videos did motivate them to study English when they are outside of the class.

I often look for English YouTube videos to learn English.

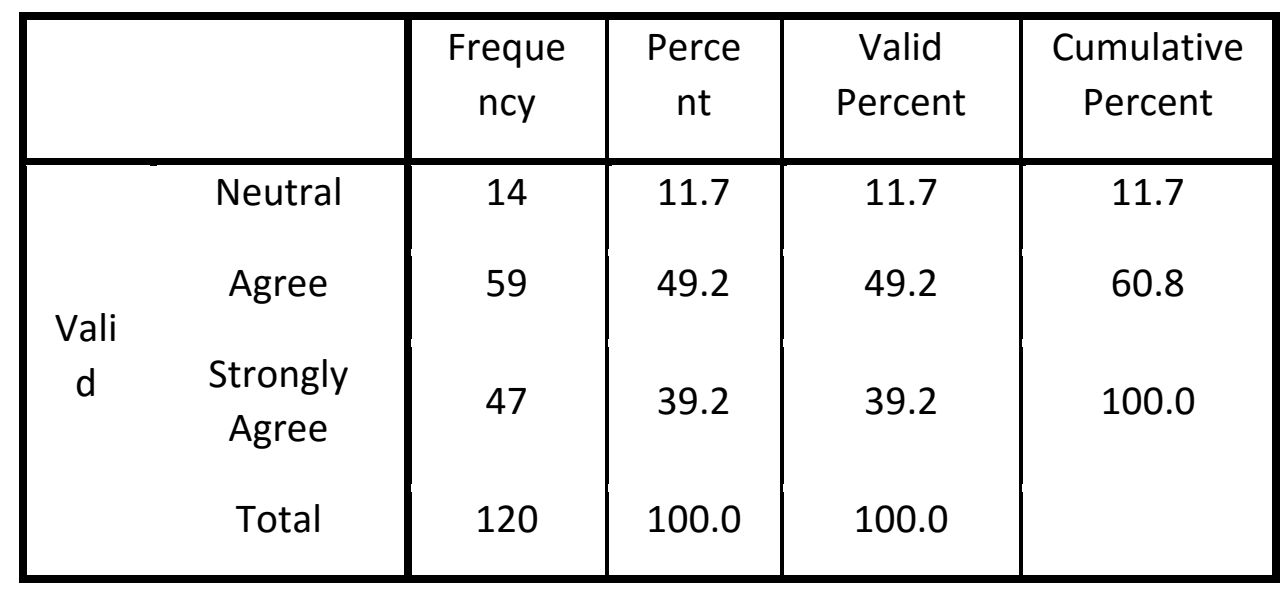

Table 8

From the table 8 , it can be seen that $49.2 \%(n=95)$ of the students agree that they often look for English YouTube videos to learn English. Whereas, 39.2\% $(n=47)$ of the students strongly agree they often look for English YouTube videos to learn English. Although majority of the students agree that they often look for English YouTube videos to learn English, there were $11.7 \%(n=14)$ of the students choose neutral on the statement. Based on the result, majority of the students did agree that they often look for English YouTube videos to learn English. 
INTERNATIONAL JOURNAL OF ACADEMIC RESEARCH IN BUSINESS AND SOCIAL SCIENCES

Vol. 10, No. 3, March, 2020, E-ISSN: 2222-6990 C 2020 HRMARS

I learn pronunciation of English words from YouTube videos.

\begin{tabular}{|c|c|c|c|c|c|}
\hline & & $\begin{array}{c}\text { Frequenc } \\
y\end{array}$ & Percent & $\begin{array}{c}\text { Valid } \\
\text { Percent }\end{array}$ & $\begin{array}{c}\text { Cumulative } \\
\text { Percent }\end{array}$ \\
\hline Valid & $\begin{array}{c}\text { Neutral } \\
\text { Agree } \\
\text { Strongly } \\
\text { Agree } \\
\text { Total }\end{array}$ & $\begin{array}{l}36 \\
48\end{array}$ & $\begin{array}{l}30.0 \\
40.0\end{array}$ & $\begin{array}{l}30.0 \\
40.0\end{array}$ & $\begin{array}{l}30.0 \\
70.0\end{array}$ \\
\hline
\end{tabular}

Table 9

From the table 9, it can be seen that $40 \%(n=48)$ of the students agree that they learn pronunciation of English words from YouTube videos. Whereas, 30\% $(n=36)$ of the students strongly agree they learn pronunciation of English words from YouTube videos. Although majority of the students agree that they learn pronunciation of English words from YouTube videos, there were $30 \%(n=36)$ of the students choose neutral on the statement. Based on the result, majority of the students agreed that they learn pronunciation of English words from YouTube videos.

The following statements were administered to investigate the students' perception in using YouTube videos.

YouTube captures my attention better.

\begin{tabular}{|c|c|c|c|c|c|}
\hline & & $\begin{array}{c}\text { Freque } \\
\text { ncy }\end{array}$ & $\begin{array}{c}\text { Perce } \\
\text { nt }\end{array}$ & $\begin{array}{c}\text { Valid } \\
\text { Percent }\end{array}$ & $\begin{array}{c}\text { Cumulative } \\
\text { Percent }\end{array}$ \\
\hline \multirow{4}{*}{$\begin{array}{l}\text { Vali } \\
\text { d }\end{array}$} & Neutral & 26 & 21.7 & 21.7 & 21.7 \\
\hline & Agree & 54 & 45.0 & 45.0 & 66.7 \\
\hline & $\begin{array}{c}\text { Strongly } \\
\text { Agree }\end{array}$ & 40 & 33.3 & 33.3 & 100.0 \\
\hline & Total & 120 & 100.0 & 100.0 & \\
\hline
\end{tabular}

Table 10

From the table 10, it can be seen that $45 \%(n=54)$ of the students agree that YouTube captures their attention better. Whereas, $33.3 \%(n=40)$ of the students strongly agree YouTube captures their 
INTERNATIONAL JOURNAL OF ACADEMIC RESEARCH IN BUSINESS AND SOCIAL SCIENCES Vol. 10, No. 3, March, 2020, E-ISSN: 2222-6990 (c) 2020 HRMARS

attention better. Although majority of the students agree that YouTube captures their attention better, there were $21.7 \%(n=26)$ of the students choose neutral on the statement. Based on the result, majority of the students did agree that YouTube captures their attention better.

YouTube is convenient, affordable and accessible.

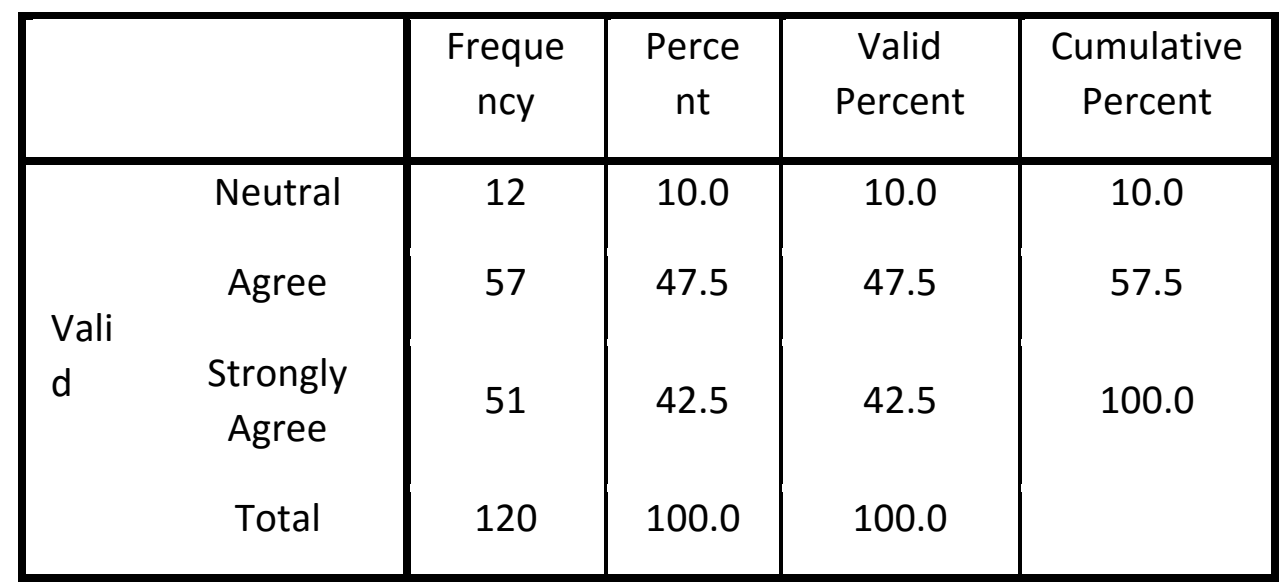

Table 11

From the table 11, it can be seen that $47.5 \%(n=57)$ of the students agree that YouTube is convenient, affordable and accessible. Meanwhile, $42.5 \%(n=51)$ of the students strongly agree YouTube is convenient, affordable and accessible. Although majority of the students agree that YouTube is convenient, affordable and accessible, there were $10 \%(n=12)$ of the students choose neutral on the statement. Based on the result, majority of the students did agree that YouTube is convenient, affordable and accessible.

YouTube helps to accomplish study tasks quicker.

\begin{tabular}{|c|c|c|c|c|c|}
\hline & & $\begin{array}{c}\text { Freque } \\
\text { ncy }\end{array}$ & $\begin{array}{c}\text { Perce } \\
\text { nt }\end{array}$ & $\begin{array}{c}\text { Valid } \\
\text { Percent }\end{array}$ & $\begin{array}{c}\text { Cumulative } \\
\text { Percent }\end{array}$ \\
\hline \multirow{4}{*}{$\begin{array}{l}\text { Vali } \\
\text { d }\end{array}$} & Neutral & 14 & 11.7 & 11.7 & 11.7 \\
\hline & Agree & 64 & 53.3 & 53.3 & 65.0 \\
\hline & $\begin{array}{l}\text { Strongly } \\
\text { Agree }\end{array}$ & 42 & 35.0 & 35.0 & \multirow[t]{2}{*}{100.0} \\
\hline & Total & 120 & 100.0 & 100.0 & \\
\hline
\end{tabular}

Table 12 
INTERNATIONAL JOURNAL OF ACADEMIC RESEARCH IN BUSINESS AND SOCIAL SCIENCES Vol. 10, No. 3, March, 2020, E-ISSN: 2222-6990 @ 2020 HRMARS

From the table 12 , it can be seen that $53.3 \%(n=64)$ of the students agree that YouTube helps to accomplish study tasks quicker. Meanwhile, 35\% $(n=42)$ of the students strongly agree YouTube helps to accomplish study tasks quicker. Although majority of the students agree that YouTube helps to accomplish study tasks quicker, there were $11.7 \%(n=14)$ of the students choose neutral on the statement. Based on the result, majority of the students did agree that YouTube helps them to accomplish their study tasks quicker.

YouTube exposed students to what happened in the outside world.

\begin{tabular}{|c|c|c|c|c|c|}
\hline & & $\begin{array}{c}\text { Freque } \\
\text { ncy }\end{array}$ & $\begin{array}{c}\text { Perce } \\
\text { nt }\end{array}$ & $\begin{array}{c}\text { Valid } \\
\text { Percent }\end{array}$ & $\begin{array}{c}\text { Cumulative } \\
\text { Percent }\end{array}$ \\
\hline \multirow{3}{*}{$\begin{array}{l}\text { Vali } \\
\text { d }\end{array}$} & Agree & 50 & 41.7 & 41.7 & 41.7 \\
\hline & $\begin{array}{l}\text { Strongly } \\
\text { Agree }\end{array}$ & 70 & 58.3 & 58.3 & \multirow[t]{2}{*}{100.0} \\
\hline & Total & 120 & 100.0 & 100.0 & \\
\hline
\end{tabular}

Table 13

From the table 13 , it can be seen that $58.3 \%(n=70)$ of the students strongly agree that YouTube exposed students to what happened in the outside world. Although majority of the students strongly agree that YouTube exposed students to what happened in the outside world, there were $41.7 \%$ $(n=50)$ of the students choose agree on the statement. Based on the result, majority of the students did strongly agree that YouTube exposed them to what happened in the outside world.

YouTube improves the quality of assignments that students produce.

\begin{tabular}{|ll|c|c|c|c|}
\hline & $\begin{array}{c}\text { Freque } \\
\text { ncy }\end{array}$ & $\begin{array}{c}\text { Perce } \\
\text { nt }\end{array}$ & $\begin{array}{c}\text { Valid } \\
\text { Percent }\end{array}$ & $\begin{array}{c}\text { Cumulative } \\
\text { Percent }\end{array}$ \\
\hline & Agree & 43 & 35.8 & 35.8 & 35.8 \\
$\begin{array}{l}\text { Vali } \\
\text { d }\end{array}$ & $\begin{array}{l}\text { Strongly } \\
\text { Agree }\end{array}$ & 77 & 64.2 & 64.2 & 100.0 \\
& Total & 120 & 100.0 & 100.0 & \\
\hline
\end{tabular}

Table 14

From the table 14 , it can be seen that $64.2 \%(n=77)$ of the students strongly agree that YouTube improves the quality of assignments that students produce. Although majority of the students strongly agree that YouTube improves the quality of assignments that students produce, there were 
INTERNATIONAL JOURNAL OF ACADEMIC RESEARCH IN BUSINESS AND SOCIAL SCIENCES Vol. 10, No. 3, March, 2020, E-ISSN: 2222-6990 @ 2020 HRMARS

$35.8 \%(n=43)$ of the students choose agree on the statement. Based on the result, majority of the students did strongly agree that YouTube improves the quality of assignments that they produce.

YouTube enables students to control their own learning.

\begin{tabular}{|ll|c|c|c|c|}
\hline & $\begin{array}{c}\text { Freque } \\
\text { ncy }\end{array}$ & $\begin{array}{c}\text { Perce } \\
\text { nt }\end{array}$ & $\begin{array}{c}\text { Valid } \\
\text { Percent }\end{array}$ & $\begin{array}{c}\text { Cumulative } \\
\text { Percent }\end{array}$ \\
\hline & Neutral & 14 & 11.7 & 11.7 & 11.7 \\
Vali & Agree & 44 & 36.7 & 36.7 & 48.3 \\
d & $\begin{array}{l}\text { Strongly } \\
\text { Agree }\end{array}$ & 62 & 51.7 & 51.7 & 100.0 \\
& Total & 120 & 100.0 & 100.0 & \\
\hline
\end{tabular}

Table 15

From the table 15, it can be seen that $51.7 \%(n=64)$ of the students strongly agree that YouTube enables students to control their own learning. Meanwhile, $36.7 \%(n=44)$ of the students agree that YouTube enables students to control their own learning. Although majority of the students strongly agree that YouTube enables students to control their own learning, there were $11.7 \%(n=14)$ of the students choose neutral on the statement. Based on the result, majority of the students did strongly agree that YouTube enables them to control their own learning.

The following statements were administered to explore the students' insights on the effectiveness of using YouTube videos.

Enables me to remember English words better.

\begin{tabular}{|c|c|c|c|c|c|}
\hline & & $\begin{array}{c}\text { Freque } \\
\text { ncy }\end{array}$ & $\begin{array}{c}\text { Perce } \\
\text { nt }\end{array}$ & $\begin{array}{c}\text { Valid } \\
\text { Percent }\end{array}$ & $\begin{array}{c}\text { Cumulative } \\
\text { Percent }\end{array}$ \\
\hline $\begin{array}{l}\text { Vali } \\
\text { d }\end{array}$ & $\begin{array}{l}\text { Neutral } \\
\text { Agree } \\
\text { Strongly } \\
\text { Agree } \\
\text { Total }\end{array}$ & $\begin{array}{c}41 \\
120\end{array}$ & $\begin{array}{l}24.2 \\
41.7\end{array}$ & $\begin{array}{l}24.2 \\
41.7\end{array}$ & $\begin{array}{l}24.2 \\
65.8\end{array}$ \\
\hline
\end{tabular}

Table 16 
INTERNATIONAL JOURNAL OF ACADEMIC RESEARCH IN BUSINESS AND SOCIAL SCIENCES Vol. 10, No. 3, March, 2020, E-ISSN: 2222-6990 ¿ 2020 HRMARS

From the table 16, it can be seen that $41.7 \%(n=50)$ of the students agree that YouTube enables them to remember English words better. Meanwhile, 34.2\% $(n=41)$ of the students strongly agree that YouTube enables them to remember English words better. Although majority of the students agree that YouTube enables them to remember English words better, there were $24.2 \%(n=29)$ of the students choose neutral on the statement. Based on the result, majority of the students did agree that YouTube enables them to remember English words better.

Enables me to know English words better.

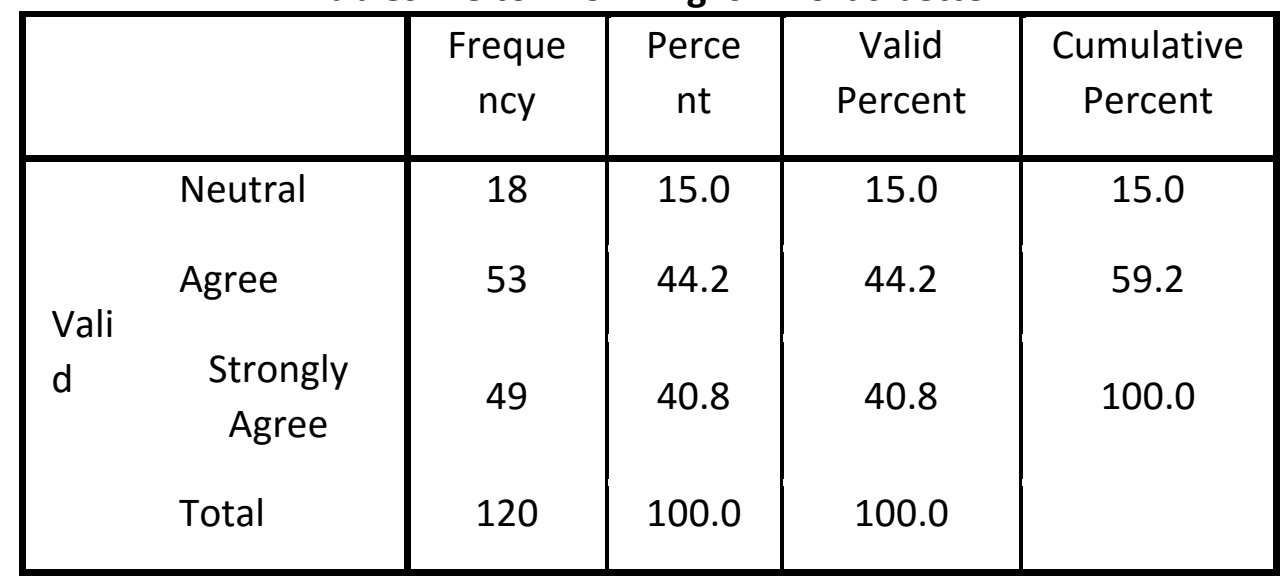

Table 17

From the table 17, it can be seen that $44.2 \%(n=53)$ of the students agree that YouTube enable them to know English words better. Whereas, $40.8 \%(n=49)$ of the students strongly agree YouTube enable them to know English words better. Although majority of the students agree that YouTube enable them to know English words better, there were $15.0 \%(n=18)$ of the students choose neutral on the statement. Based on the result, majority of the students did agree that YouTube enable them to know English words better.

Enables me to learn the correct sentence structure better.

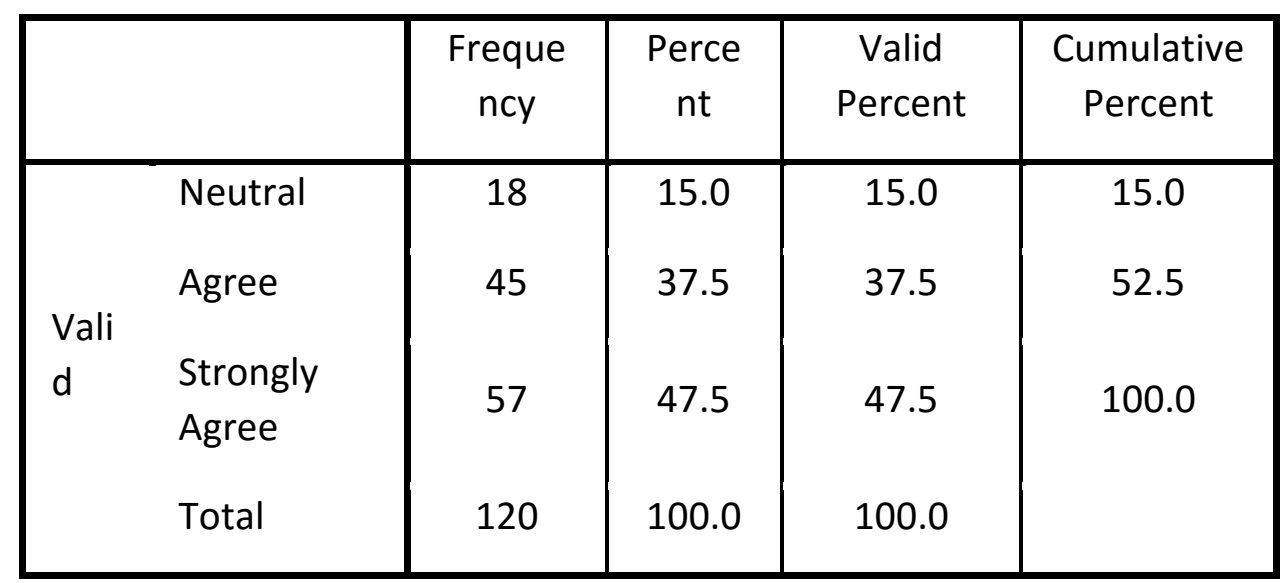

Table 18 
From the table 18 , it can be seen that $47.5 \%(n=57)$ of the students strongly agree that YouTube enable them to learn the correct sentence structure better. Whereas, $37.5 \%(n=45)$ of the students agree YouTube enable them to learn the correct sentence structure better. Although majority of the students strongly agree that YouTube enable them to learn the correct sentence structure better, there were $15.0 \%(n=18)$ of the students choose neutral on the statement. Based on the result, majority of the students did strongly agree that YouTube enable them to learn the correct sentence structure better.

Enables me to remember the correct sentence structure better.

\begin{tabular}{|ll|c|c|c|c|}
\hline & $\begin{array}{c}\text { Freque } \\
\text { ncy }\end{array}$ & $\begin{array}{c}\text { Perce } \\
\text { nt }\end{array}$ & $\begin{array}{c}\text { Valid } \\
\text { Percent }\end{array}$ & $\begin{array}{c}\text { Cumulative } \\
\text { Percent }\end{array}$ \\
\hline & Neutral & 29 & 24.2 & 24.2 & 24.2 \\
Vali & Agree & 51 & 42.5 & 42.5 & 66.7 \\
d & $\begin{array}{l}\text { Strongly } \\
\text { Agree }\end{array}$ & 40 & 33.3 & 33.3 & 100.0 \\
& Total & 120 & 100.0 & 100.0 & \\
\hline
\end{tabular}

Table 19

From the table 19, it can be seen that $42.5 \%(n=51)$ of the students agree that YouTube enable them to remember the correct sentence structure better. Whereas, 33.3\% $(n=40)$ of the students strongly agree YouTube enable them to remember the correct sentence structure better. Although majority of the students agree that YouTube enable them to remember the correct sentence structure better, there were $24.2 \%(n=29)$ of the students choose neutral on the statement. Based on the result, majority of the students did agree that YouTube enable them to remember the correct sentence structure better.

In order to have a better understanding of the students' insight on the effectiveness of the usage of the YouTube video in the rural ESL classroom, students were asked about their suggestions and comments about the usage of YouTube videos.

Out of all of the samples, only 12 students made extra suggestions or comments. There are a few extra suggestions or comments made by the students. Their positive response or remarks comprised of "YouTube videos are fun.", "Use more YouTube videos in the classroom.", "It is interesting.", "I hope teachers use more of YouTube.", and "I want to use YouTube in the class every day.". Furthermore, one of the students suggested that "Teachers should use YouTube for every lesson.". Meanwhile, another student wrote "YouTube is fun but do not use it too much in the class.". 
INTERNATIONAL JOURNAL OF ACADEMIC RESEARCH IN BUSINESS AND SOCIAL SCIENCES Vol. 10, No. 3, March, 2020, E-ISSN: 2222-6990 @ 2020 HRMARS

Moreover, another student suggested "Use short YouTube videos in the class.". Other comments or suggestions included "YouTube can be used by the students in the classroom for pre-lesson and conclusion of the lesson.", "Teacher can let the students choose what video they want to watch in the YouTube as a reward.", "Do not overuse YouTube in the class." and "I need YouTube to learn English better.". Overall, the findings shown that students mostly liked and benefited from the use of YouTube in the rural ESL classroom.

\section{Discussion}

The literature that was reviewed in the earlier part has helped in highlighting the importance of YouTube as a tool to engage web generation learners (Duffy, 2008). Hence, based on the findings, it has shown that all respondents were using YouTube to help them learn the English language.

To answer the first research question which was to find out the interests of the students in the usage of YouTube in learning English at a particular rural primary school in Niah, Sarawak, the research has found that the students were interested to look for English YouTube videos as one of the tools to learn the English language. It is found that $49.2 \%$ agree that they often look for English YouTube videos to learn English, $39.2 \%$ strongly agree and only $11.7 \%$ feeling neutral in learning English using YouTube.

Fleming and Mills (1992) stated that visual learners prefer to see visual aids for their learning. Furthermore, from the analysis, 36.7\% strongly agreed and 52.5\% agreed that watching YouTube videos did motivate them in studying English when they were outside of the classroom. Meanwhile only $10.8 \%$ neutral to the statement. This proved that the use of YouTube videos has a strong effect on the students' mind and senses as supported by Berk (2009) who claimed that using YouTube videos can seize the attention of the pupils, improve attention retention, produce interests in the lessons and improve attitudes towards content (Berk, 2009).

Respondents were asked whether they were able to understand English lessons easier after engaging with YouTube videos and it can have been seen that $54.2 \%$ of the students agreed and $35.8 \%$ strongly agreed that watching YouTube videos did help them to understand English better and only $10 \%$ neutral to the statement. Therefore, watching English YouTube videos as a medium of instruction, could help in enhancing the understanding of the knowledge (Green \& Tanner, 2005).

The second research question of this research paper was to examine the students' perceptions of using YouTube in the ESL classroom at a particular rural primary school in Niah, Sarawak. Based on the results, $41.7 \%$ of the respondents' agreed and $58.3 \%$ strongly agreed that YouTube did helped to expose them to what happened in the outside world. This was proven by Kreisen (2009) who claimed that YouTube videos is helping students to learn more about various cultures since the sources of the videos in the YouTube are shared by users of variety of background throughout the world. Besides that, $64.2 \%$ of the respondents strongly agreed and $35.8 \%$ agree that watching YouTube videos aided them to improve the quality of the assignments produced. This proved a claimed by Tan and Pearce (2012) that YouTube videos aided students and was an effective way to support their learning.

According to the results, the findings also showed that $47.5 \%$ of the students agreed and $42.5 \%$ strongly agreed that browsing through the YouTube was very convenient, affordable and easy to access and only $10 \%$ neutral to the statement. It was rather easy to gain access to YouTube because it is a free access video sharing website (Duffy, 2008). As stated earlier, this website has more than 
INTERNATIONAL JOURNAL OF ACADEMIC RESEARCH IN BUSINESS AND SOCIAL SCIENCES Vol. 10, No. 3, March, 2020, E-ISSN: 2222-6990 @ 2020 HRMARS

one billion visitors every month and thousands of videos and topics in many languages are shared and are available on YouTube.

Moreover, the students were asked if YouTube improved the quality of the assignments they produced and the finding showed that $35.8 \%$ of the respondents agreed and $64.2 \%$ strongly agreed with the statement.

The third research question of this paper is to explore the students' insights on the effectiveness of the usage of YouTube in learning English at a particular rural primary school in Niah, Sarawak. Based on the result, it can be seen that $41.7 \%$ of the students agree that YouTube enables them to remember English words better. Meanwhile, 34.2\% of the students strongly agree that YouTube enables them to remember English words better. Although majority of the students agree that YouTube enables them to remember English words better, there were $24.2 \%$ of the students choose neutral on the statement. Based on the result, it can be seen that majority of the students agreed that YouTube enables them to remember English words better. The students agreed that YouTube is effective in helping them to remember English word better.

Moreover, based on the result, it can be seen that $44.2 \%$ of the students agree that YouTube enable them to know English words better. Whereas, $40.8 \%$ of the students strongly agree YouTube enable them to know English words better. Although majority of the students agree that YouTube enable them to know English words better, there were $15.0 \%$ of the students choose neutral on the statement. Based on the result, majority of the students did agree that YouTube enable them to know English words better. The students agreed that YouTube is effective in helping them to know English word better.

Other than that, based on the result, it can be seen that $47.5 \%$ of the students strongly agree that YouTube enable them to learn the correct sentence structure better. Whereas, 37.5\% of the students agree YouTube enable them to learn the correct sentence structure better. Although majority of the students strongly agree that YouTube enable them to learn the correct sentence structure better, there were $15.0 \%$ of the students choose neutral on the statement. Based on the result, majority of the students did strongly agree that YouTube enable them to learn the correct sentence structure better. The students agreed that YouTube is effective in helping them to learn the correct sentence structure better.

In addition, based on the result, it can be seen that $42.5 \%$ of the students agree that YouTube enable them to remember the correct sentence structure better. Whereas, $33.3 \%$ of the students strongly agree YouTube enable them to remember the correct sentence structure better. Although majority of the students agree that YouTube enable them to remember the correct sentence structure better, there were $24.2 \%$ of the students choose neutral on the statement. Based on the result, majority of the students did agree that YouTube enable them to remember the correct sentence structure better. The students agreed that YouTube is effective in helping them to remember the correct sentence structure better.

The last research question is exploring the students' suggestions and comments about the usage of YouTube in learning English at a particular rural primary school in Niah, Sarawak. Overall, the findings revealed that students mostly liked and benefited from the use of YouTube in the rural ESL classroom. Thus, YouTube does have an impact on the learning of the students.

However, even though YouTube is seen as a useful platform for the learning of English in the rural classroom and could help to boost and enhance students' understanding as well as assisting the 
INTERNATIONAL JOURNAL OF ACADEMIC RESEARCH IN BUSINESS AND SOCIAL SCIENCES

Vol. 10, No. 3, March, 2020, E-ISSN: 2222-6990 @ 2020 HRMARS

students' in completing their tasks, the extent of the usefulness of the YouTube content can help students produce quality assignments still require further research.

\section{Limitations and Future Study}

One of the limitations of this study were that the sample size was relatively small and it did not represent the whole rural areas. Moreover, the sample of the respondents has lesser male respondents. Thus, it is difficult to make gender comparisons.

Finally, the fact that all the participants came from the rural area indicate that the results should not be generalized to the overall student population.

For future research, it is suggested that researchers use larger sample size. Other than that, students from various rural areas should be invited to participate in the future study. Thus, this will help the teacher to examine the impact of such technology on students' proficiency and assist educators in developing ESL teaching strategies.

\section{Conclusion}

The findings in this study extended our knowledge regarding students' perceptions on the usage of YouTube in the rural classroom. To be specific, the findings revealed that majority of the learners preferred to use YouTube as a tool for their learning. Based on the data, it implies that the students preferred to use YouTube videos in learning the English language. The students favour the usage of YouTube in their formal or informal learning. Furthermore, it is revealed that YouTube helped to enhance their learning process and ease their understanding. They acquire knowledge from watching YouTube videos.

This study contributed to the literature by providing new information on the students' perception on learning English language through YouTube. Additionally, the findings revealed that most learners acknowledged that the usage of YouTube in their learning is suitable with their learning styles. This awareness of learning styles could help students to progress in learning in a more effective way. In short, the learners will have the potential to improve their English language learning by using YouTube. The understanding of this learning process is crucial to improve the students' learning progressively. The implications of this study can be used by teachers to guide the learners in their English lessons. Teachers should know the learning strategies preferred by learners in order to make the full potential of the learners in learning the language. These findings actually benefit us, teachers the most. Teachers are able to discover their learners' learning styles and language learning strategies which is very important for a successful language learning.

The study concludes that the learners in today's generation have different styles due to their awareness of the existence of the technology. As the learners in this study were mostly from intermediate class, it is important for other researchers to do further study for learners of beginners proficiency class.

\section{References}

Berk, R. A. (2009). Multimedia teaching with video clips: TV, movies, YouTube, and mtvU in the college classroom. International Journal of Teaching and Learning, 5(1), 1-21.

Brünner, I. (2013). Using Language Learning Resources on YouTube. International Conference "ICT for language learning'. 6th edition. Libreriauniversitaria.it. Retrieved on September 102015 
INTERNATIONAL JOURNAL OF ACADEMIC RESEARCH IN BUSINESS AND SOCIAL SCIENCES

Vol. 10, No. 3, March, 2020, E-ISSN: 2222-6990 @ 2020 HRMARS

from: http://conference.pixelonline.net/ICT4LL2013/common/download/Paper_pdf/215-

ELE13FP-Bruenner-ICT2013.pdf

Duffy, P. (2008). Engaging the YouTube google-eyed generation: Strategies for using Web 2.0 in teaching and learning. The Electronic Journal of e-Learning, 6(2), 119-130.

Fill, K., \& Ottewill, R. (2006). Sink or swim: taking advantage of developments in video streaming, Innovations in Education and Teaching International, 43, 4, pp 397-408.

Fleming, N. D., \& Mills, C. (1992). Not another inventory, rather a catalyst for reflection. To Improve the Academy, (11), 137-159.

Gunadevi, K. J. S., Fathimah, P. A., \& Raja, N. S. (2013). Politechnic students' perceptions of YouTube usage in the English oral communication classroom. International Journal of Asian. Retrieved on October 2015 from http://www.pakacademicsearch.com

Green, C. \& Tanner, R. (2005), Multiple intelligences and online teacher education. ELT Journal, 54, 4, pp $312-321$.

Klimova, B. F., \& Poulova, P. (2014). ICT as a motivational tool in the learning of foreign languages. Proceedings of the 2014 International Conference on Educational Technologies and Education. 53-56.

Kreisen, B. (2009). Teaching EFL to the iGeneration: A survey of using YouTube as supplementary material with college EFL students in Taiwan. CALL-EJ Online, 10(2), 1-18.

Mishna, F., Saini, M., \& Solomon, S. (2009). Ongoing and online: Children and youth's perceptions of cyber bullying. Children and Youth Services Review, 31(12), 1222-1228.

Nagy, A., \& Kölcsey, A. (2017). Generation Alpha: Marketing or Science. Acta Technologica Dubnicae. doi: 7. 10.1515/atd-2017-0007.

Prensky, M. (2001). Digital natives, Digital immigrants Part 1. On the Horizon, 9(5), 1-6.

Roodt, S., \& Peier, D. (2013). Using Youtube in the Classroom for the Net Generation of Students. Issues in Informing Science and Information Technology. doi: 10. 473-488.

Roodt, S., \& De Villiers, C. (2011). Using YouTube as an innovative tool for collaborative learning at undergraduate level in tertiary education. Proceedings of the AIS SIG-ED IAIM 2011 Conference.

Snelson, C. (2009). Web-based video for e-learning: Tapping into the YouTube phenomenon. Collective intelligence and e-learning 2.0: Implications of web-based communities and networking (pp.147-166).

Snelson, C. (2011). YouTube across the disciplines: A review of the literature. MERLOT Journal of Online Learning and Teaching, 7(1), 159-169. Social Science, (2013). 3(9):1962-1966.

Stempleski, S., \& Tomalin, B. (2001) Film. New York: Oxford University Press.

Tan, E., \& Pearce, N. (2012) Open education videos in the classroom: Exploring the opportunities and barriers to the use of YouTube in teaching introductory sociology. Research in Learning Technology, 19, 128-137.

Watkins, J., \& Wilkins, M. (2011). Using YouTube in the EFL Classroom. Language Education in Asia, 2(1), 113-119.

Willmot, P., Bramhall, M., Radley, K. (2012) Using digital video reporting to inspire and engage students. Retrieved from http://www.raeng.org.uk/education/hestem/heip/pdf/Using_digital _ video_reporting.pdf 
INTERNATIONAL JOURNAL OF ACADEMIC RESEARCH IN BUSINESS AND SOCIAL SCIENCES

Vol. 10, No. 3, March, 2020, E-ISSN: 2222-6990 @ 2020 HRMARS

Whatley, J., \& Ahmad, A. (2007). Using video to record summary lectures to aid students' revision. Interdisciplinary Journal of E-Learning and Learning Objects, 3, 185-196. Retrieved from http://ijello.org/Volume3/IJKLOv3p185-196Whatley367.pdf

Zaidi, A., Awaludin, F. A., Karim, R. A., Ghani, N. F. C., Rani, M. S. A., \& Ibrahim, N. (2018). University Students' Perceptions of YouTube Usage in (ESL) Classrooms. International Journal of Academic Research in Business and Social Sciences, 8(1), 541-553. 